\title{
Teaching monetary theory and monetary policy implementation after the crisis*
}

\author{
Marc Lavoie \\ University of Ottawa, Canada
}

The author reflects on the state of macroeconomic theory, and more specifically on how monetary economics is being taught in the aftermath of the global financial crisis. Whereas heterodox macroeconomic theory is very much alive due to the influx of a large number of contributions and contributors, the latter still have a hard time finding positions in the academic world, as journal and departmental ranking exercises have restricted so-called standards of excellence to the neoclassical approach. The crisis has not yet induced mainstream economists to open up to different approaches that put more emphasis on realistic features than on imaginary ones based on neoclassical microfoundations. As an exemplar, the chapters on money and banking in two first-year textbooks are being examined, an orthodox one by Greg Mankiw and a heterodox one by Neva Goodwin et al. Unsurprisingly there is little to be learned about the crisis from Mankiw's book, while the book by Goodwin et al. devotes a large amount of space to the causes and consequences of the crisis. Still, Goodwin and her co-authors are not heterodox enough: they are less heterodox than a number of central bankers when it comes to a number of key features of monetary theory.

Keywords: teaching economics, realism, DSGE models, fractional-reserve banking, post-Keynesian economics

JEL codes: $A 11, A 2, E 5$

\section{INTRODUCTION}

In this article I wish to briefly discuss the precarious state of heterodox economics in the profession, and, as the title implies, I wish to review how monetary economics is being taught at the introductory level in economics textbooks.

\footnotetext{
* Paper presented at the FMM conference in Berlin, October 2014, in the session 'Teaching economics after the crisis: reform of or alternatives to the mainstream?'. Sebastian Gechert, the chair of the session, when he announced the title of the session on its eve, said that he was looking forward to getting answers about how alternatives could be or should be introduced in the economics curriculum and what strategies should be pursued to this end. As he spoke I realized that I had prepared no answer to these very important questions. However, while I will say nothing about these here, based on my personal experience I did attempt to tackle these issues at a previous conference. My thoughts on these can be found in a chapter of the book on teaching post-Keynesian economics that was edited by the organizers of that conference, Jesper Jespersen and Mogens Madsen (Lavoie 2013). Also, elsewhere (Lavoie 2012), I have put forward some reflections about the future of post-Keynesian and heterodox economics after the crisis, along with a review of the various pieces of advice that have been offered to economists who wish to go beyond a reform of the mainstream. With Fred Lee, who most unfortunately for all of us passed away, I have also collected the views of many other colleagues on the future of heterodox economics, some of whom also presented possible strategies about how best to modify the economics curriculum in universities (Lee/Lavoie 2013).
} 
Before I get into those two issues, let me start with two anecdotes, first a bad one and then one that provides a modicum of hope about the possibility of change. At the very height of the global financial crisis, in 2009, a few months after the collapse of Lehman Brothers and its accompanying chaos, our graduate programmes in economics at the University of Ottawa came under review, as they are every 7 years. As such, two respected external reviewers audited our programmes. During a meeting with all the members of the department, one of the examiners, from the prestigious McGill University in Montreal, no less, told us that we needed to offer more mathematics in order to better train our students. I asked in what way more mathematics was going to help our students to better explain the causes and consequences of the financial crisis. The question was met with a deafening silence, both from my colleagues and from the examiner.

My second anecdote concerns a session of the Canadian Economics Association 2013 annual meeting, which was held in Montreal. The session was dedicated to macroeconomics for undergraduates after the crisis. A panellist from McGill University, Christopher Ragan, the author of the Canadian version of the Lipsey first-year textbook, explained how he had created a course on the financial crisis, in which his students were reading books by Galbraith, Kindleberger, Minsky and others. I was much impressed by this initiative, as I thought that it did offer a glimmer of hope that things can change. ${ }^{1}$ The other two panellists, however, were less encouraging. Their message was that now they felt compelled to spend more time on the chapter covering money and banking. But in no way would they rethink the theoretical monetary approach and the macroeconomics that are found in mainstream textbooks.

\section{ON THE DIFFICULTY OF REFORMING THE MAINSTREAM}

I hesitated quite a lot before proposing a title for the present article. I first wrote down these two titles:

'Reform is not enough: there is no alternative: drop economics and create a new field of radical political economics', or:

'There is an urgent need for alternatives to the mainstream: but where will they be taught?'

These sound rather gloomy, and indeed I am a bit worried about the future of alternative theories in economics. I remember having had a conversation with Paul Davidson in the early 1990s, during which I was quite surprised to discover how so pessimistic he was about the future of post-Keynesian economics. Still, here we are, 20 years later: Paul is still fighting for his brand of Keynesian economics and he is still trying to hold on to the Journal of Post Keynesian Economics. And since the early 1990s many new heterodox journals have been created (including EJEEP: Intervention); several new post-Keynesian writers have appeared on the academic scene and have managed one way or another to find an academic position; there seems to be a flurry of projects dedicated to the conception of heterodox textbooks or material for students that are at the introductory or intermediate level; there are more young scholars studying and writing about post-Keynesian economics than there ever was, as far as I can assess it; and the post-autistic movement that had been started by French students in 2000 is being reinvigorated in various new incarnations such

1. On the other hand, Ragan (2014) has more recently defended Economics 101 against those who believe that economics professors fill the heads of students 'with oversimplified assumptions, obsessing with the mathematics of theoretical models and failing to teach them about economic phenomena in the real world'. There was no indication of possible change in his defence of mainstream economics. 
as the Young Scholar Initiative or the International Student Initiative for Pluralism in Economics (2014) and their numerous participating bodies. Indeed, browsing through the papers that are on the website of the 2014 FMM conference in Berlin, one can only be impressed by the extraordinary number of good papers that are being presented, including those in the sessions devoted to the work of graduate students.

On the negative side, we see that there is an even stronger emphasis in most economics departments (good and bad ones) to publish in places that only accept a specific kind of economics, essentially based on constrained maximization, so that young spirits, despite being distrustful of mainstream economics, are still pressured to publish what is acceptable in these journals for fear of not being tenured or promoted. The situation got worse when tenure-track positions in universities and in economics departments in particular became a scarce commodity, as the supply of new doctorate holders started to completely outpace the creation of such new jobs. The dice became loaded for good when output metrics based on articles published in quality-weighted journals became fashionable. ${ }^{2}$ To his credit, Frederic Lee quickly identified the dangers of such measurements for pluralism and eclecticism, criticizing the British research quality assessment exercise, which became a template for many other countries, and predicting that it would bring to an end the hiring of academics holding alternative views (Lee/Harley 1998). At the time, Lee was accused of not playing ball, of being overly critical, of lacking diplomacy and of endangering communication between orthodox and heterodox economists. But Lee's assessment of the evolution of academic economics as a consequence of these biased ranking exercises, in Britain and elsewhere, turned out to be fully prescient, as is recognized by Colander (2010: 425). This did not happen for lack of engagement: in all countries - in the UK, in France, in Italy - heterodox economists did participate in these journal or department ranking exercises, trying to tame the tide. So far, the best defence has been to propose alternative ranking methods that provide better support to our heterodox journals (Lee/Elsner 2010).

Sometimes, one gets the feeling that the only solution is to create a new field, for instance radical political economy or radical political economics, as the French Association of Political Economy (Association française d'économie politique, AFEP) is attempting to do right now with its proposed new field 'Economics and Society', and hope that it will be just as successful as the new field in political science - international political economy which has obvious ties with heterodox economics. About 15 years ago, with my long-time colleague Mario Seccareccia and a couple of other heterodox colleagues, I was asked by our dean to join the School of Political Science and start a program in political economy. We declined to do so, thinking that this was a thinly disguised attempt to cleanse the department of its heterodox elements and also believing that we were bona fide economists and hence that we belonged to a department of economics. Retrospectively, from an institutionbuilding point of view, this was perhaps not a good decision, as we now have no influence whatsoever on recruitment in our economics department and in neighbouring departments such as public affairs or international development and globalization.

On the positive side, there are still a few countries, like Brazil, where heterodox economics is a welcomed alternative, as transpires from the interview with Fernando de Carvalho (Lavoie/Niechoj 2013). In addition, a number of economics departments, which few had heard of before, have emerged as new centres of post-Keynesian or heterodox economics. And there are some initiatives, such as the Institute for New Economic

2. John McCombie (2015: 246-247) in his review of my book (Lavoie 2014) also fears that these metric exercises will condemn heterodox economics to obscurity in the academic world, despite the appetite of students for alternatives. 
Thinking (INET), whose purpose includes alleviating the fears of young scholars and inducing them to continue in their plans to study and research in heterodox economics, in the hope that they will have a career just as successful as their elders while sticking to their guns.

Unfortunately, the Curriculum Open-access Resources in Economics (CORE) project, subsidized by INET and led by Wendy Carlin, whose initial goal was to transform the way economics is being taught, seems to be an exercise in modifying the form rather than the contents of courses in principles of economics, as has been argued in excruciating detail by Jamie Morgan (2014) in his assessment for the British Association for Heterodox Economics. I must say that I got the same impression when one of Carlyn's co-researchers presented the CORE INET program at the INET meeting in Toronto in April 2014. ${ }^{3}$

The consensus among orthodox economists seems to be that there is no need for an across-the-board critique or rejection of mainstream economics. All that is needed is some improvement in the current orthodox theory, which can be achieved by modifying some of the assumptions situated outside of the core of neoclassical economics. In the field of macroeconomics, for instance, as Jamie Morgan (2014: 10) rightly recalls, the consensus seems to be that 'the current approach to macroeconomic modelling needs augmenting rather than repudiating'. The claim here is that orthodox theory or modelling, despite its technical virtuosity, is overly simple, and hence is in need of more frictions, asymmetric information, liquidity constraints, heterogeneous agents and complexity.

As an example of this attitude, one can cite the IMF chief economist, Olivier Blanchard (2014: 31), who argues that 'DSGE models should be expanded to better recognize the role of the financial system'. This, he claims, is being done right now. Blanchard recognizes that these models are useless when the economy is found to be away from eras of the Great Moderation, but this does not matter because he believes that with the improved models, the economy will stay away from what he calls 'the dark corners', where mainstream models can provide no light. The British call this wishful thinking. At least Blanchard appears more reasonable than other (fairly well-known) neoclassical economists who claim that 'any interesting model must be a dynamic stochastic general equilibrium model. From this perspective, there is no other game in town ... If you have an interesting and coherent story to tell, you can tell it in a DSGE model. If you cannot, your story is incoherent' (V.V. Chari, as quoted by Garcia Duarte, 2012: 220). ${ }^{4}$ How much more open-minded can orthodox economics be?!

Another example of such an attitude is that of the writer of the book Big Ideas in Macroeconomics, devoted to an exposition of the macroeconomic extensions of the Arrow-Debreu-McKenzie model. The author, Kartik Athreya (2013: 359), argues that the failure to produce a forecast of a huge downturn '[does] not make a wholesale revamping of macroeconomics a bright idea'. All that is needed is a change in the emphasis of research, by spending more time on the role of banks or finance. 'Internally driven reform is happening' (ibid.: 363), he says, but slowly, because it is so difficult technically to insert into DSGE models essential aspects such as the real estate market, banks and so forth. The answers, he concludes, are not in Keynes, Hayek or Minsky.

3. Students active in the various movements for a reform of the economics curriculum also appear to be puzzled by the direction taken by the project. For an excellent critique arising from the student side, see, among others, Reissl (2014).

4. I heard Michael Kumhoff, from the IMF, make a very similar statement at the 'State of economics after the crisis' FMM Berlin conference in October 2012, despite the fact that some see him as a mainstream economist holding somewhat eclectic views. 
They are to be found in neo-Walrasian models, where expectations about the future course of prices are the driving force.

The problem, as I and others see it, is not that neoclassical economists or neoclassical models did not forecast the sub-prime crisis nor that they could not forecast such a crisis. For instance, despite being a close collaborator of Wynne Godley, who since 1999 had produced a nearly continuous flow of warnings about possible recessions due to impending stock-market crashes, real estate crashes and unsustainable processes, I did not myself pay much attention to the deteriorating conditions of the US real-estate market in 2006. The problem, from the standpoint of someone who was never brainwashed enough by neoclassical economics, is that going through the advanced textbooks of Athreya, Wickens, Galí and others, what one finds is an extraordinary number of totally unrealistic assumptions, which are claimed to be simplifications or abstractions, when actually they apply to a totally imaginary world - a fantasy world - which has no relationship whatsoever with the world in which we live. ${ }^{5}$ This was recognized a long time ago by the likes of Hahn and Bliss, and it has recently been pointed out by Colander/Rothschild (2009: 126-127) when they admit that the DSGE model involves idealizing to a world we can fully understand in the hope that understanding this simplified world will help us better understand our own', although, surprisingly, they conclude one page later that 'thanks to DSGE we know more than we used to about the economy'.

Orthodox economists, even many dissident orthodox authors, dress up their unrealistic foundations with realistic auxiliary hypotheses. The question, then, is whether it is possible to arrive at a model that describes the real world adequately by adding auxiliary realistic characteristics to totally unrealistic core assumptions which, among many other features, preclude any useful role for money, banks and central banks. As recalled by Colin Rogers (2014: 302), this is an impossible and self-contradictory task because 'all contemporary or "new" monetary models contain a WAD [Walrasian-Arrow-Debreu] general equilibrium core onto which are appended various ad hoc structures that are intended to represent some element of reality, particularly money, that is not captured by the WAD core'. In all cases, money is an inessential addition.

Kaldor, in two papers published in 1966 and 1972 also argued that such a thing (rescuing models that are fundamentally antagonistic to our world by adding auxiliary assumptions that carry some realistic appearance) was not possible. He wrote: 'The process of removing the "scaffolding", as the saying goes - in other words of relaxing the unreal basic assumptions - has not yet started. Indeed the scaffolding gets thicker and more impenetrable with every successive reformulation of the theory, with a growing uncertainty as to whether there is a solid building underneath' (Kaldor 1972: 1239). I dare say that the situation is even worse today than it was 40 years ago.

\section{TEACHING MONETARY ECONOMICS}

As I have now touched upon the role of money in 'state-of the-art' economic models, let me move to the title of my presentation, and discuss the teaching of monetary economics. The question put to us is whether there should be reform of the mainstream or the promotion of

5. Laurent Cordonnier (2014) has, however, written a novel where he imagines that everyone is constantly checking the evolution of prices on their apps because all prices are fully flexible. Everything has a forward market, including drinks and seating at a restaurant, and hence everyone is constantly making capital gains or losses. Individuals may, however, go bankrupt, which makes his novel more realistic than standard DSGE models with their transversality and no-default condition. 
alternatives. Let me look at two examples of introductory textbooks of macroeconomics, one written by five heterodox authors, the first edition of which I reviewed for EJEEP a few years ago (Lavoie 2009), and another written by a mainstream author, Greg Mankiw.

Mankiw (2015), as one would expect, has all the standard mainstream features: there is a loanable funds explanation of interest rates, more saving leads to lower interest rates, and government deficits lead to crowding out and higher interest rates. Mankiw gives his full support to the quantity theory of money, the causal relationship between money supply growth and price inflation, a money creation mechanism based on the money multiplier process and the fractional-reserve banking system, and the belief that a rate of interest on bank reserves will reduce money creation - all false beliefs. On the good side, there is a box devoted to the quantitative exit $(\mathrm{QE})$ strategy of the Fed, a discussion of leverage and of the zero-lower bound, but that is all. Is it any better in textbooks by heterodox authors?

Neva Goodwin, Jonathan Harris and their three co-authors have several good things in the second edition of their macro textbook (2014): they recognize that central banks target interest rates, not money aggregates, and they distinguish clearly between the fed funds target and the actual fed funds rate. They describe the various components of the shadow-banking system; they discuss financialization, speculation and financial bubbles. In the second edition, unlike the first, the single chapter on banks and the central bank has been split into two chapters, thus obviously giving more importance to money matters - a welcomed symptom of my second anecdote. In addition, the second edition contains a new chapter entirely devoted to the sub-prime financial crisis and the Great Recession. There, they criticize the stock options and bonuses of CEOs, and they have a whole section on income inequality as a possible cause of the crisis, claiming that a perception of falling living standards led the middle class to overly expand their debt-to-income ratios. Thus there is plenty of relevant stuff about the financial system in the book, and clearly the financial crisis had a large effect on its contents, in contrast to the Mankiw book.

However, there is some evidence of retrogression when comparing the first and the second editions. In the first edition, the downward-sloping shape of the aggregate demand curve was explained by the fact that the central bank would increase interest rates when it would take notice of higher inflation rates. In the second edition, this is mainly explained as a wealth effect, as in standard textbooks. In addition, we are now told that 'expansionary monetary policy should tend to lower interest rates' (Goodwin et al. 2014: 277), thus leaving us with the impression that the lower interest rates are the secondary effect of an increase in highpowered money rather than a decision of the central bank to target a lower interest rate.

Coming now to the dark side of the book, Goodwin, Harris and their co-authors give full approval to the quantity theory of money, claiming that it explains inflation. There is no discussion of the possibility of reversed causation - that is, of nominal GDP growth causing money supply growth. We are told that deflation is really bad for the economy, without being told why this is so (presumably because of the weight of debt or because of expectations about future lower prices, as explained by Keynes already in 1936), while the contradiction with the next chapter, devoted to aggregate demand, where it is assumed that lower inflation increases output, is left unnoticed. Goodwin, Harris et al. state a number of times that more deposits allow banks to make more loans (ibid.: 252, 257, 260), as if banks were merely financial intermediaries. They further explain that QE increases bank reserves and hence the money supply 'because holding more reserves enables banks to offer more loans to the public' (ibid.: 357), and thus conclude that if QE was only moderately successful it must be because 'banks remain reluctant to lend their excess reserves' (ibid.: 358).

All these claims are consistent with what Basil Moore (1988) called the verticalist story in his book published more than 25 years ago. It is the mainstream description of the money multiplier in a fractional-reserve banking system, where the supply of money 
and hence the supply of loans is determined by the creation of high-powered money through the open-market operations of the central bank, as is presented in the chapter on central banks. The only difference from the standard story is the addition of the case of the liquidity trap, where banks are presumed to hold onto their excess reserves while non-financial agents hold onto their money balances.

Unfortunately, one cannot have it both ways, as I had already pointed out in my book review of the first edition (Lavoie 2009). As already mentioned in a sarcastic note by Charles Goodhart (2009: 825), one cannot argue that the Fed lets the monetary base supply adjust to the demand for base money in order to keep the federal funds rate at its target level while claiming simultaneously that the supply of money is determined by the monetary base, and hence that the supply of money is exogenous. These two statements are inconsistent with each other. In addition, the latter causal process is incongruous with the way banks create money, with the operating procedures of central banks and with accounting. As pointed out in a 2014 Quarterly Bulletin of the Bank of England, 'reserves cannot be multiplied into more loans and deposits, and reserves do not represent "free money" for banks' (McLeay et al. 2014: 1). Indeed the British central bankers point out that there are two misconceptions, which have long been pointed out by post-Keynesians such as Basil Moore (1988):

One common misconception is that banks act simply as intermediaries, lending out the deposits that savers place with them. In this view deposits are typically 'created' by the saving decisions of households and banks then 'lend' out those existing deposits to borrowers ... Another common misconception is that the central bank determines the quantity of loans and deposits in the economy by controlling the quantity of central bank money - the so-called 'money multiplier' approach. (McLeay et al. 2014: 15)

The same misconceptions are underlined by Fed officials (Keister et al. 2008; Keister/ McAndrews 2009). Thus, as is confirmed by an ECB banker, 'central bankers have by now largely buried "verticalism", at least when it comes to monetary policy implementation' (Bindseil/König 2013: 385), verticalism being a reference to the title of Moore's (1988) book. It is a bit ironic that a textbook that claims to engage in critical thinking and eclecticism still ignores the work and theories of a post-Keynesian author who is now recognized by central bankers from the Bank of England and the European Central Bank as having provided 'a key contribution to monetary economics ... that stood the test of time' (ibid.: 389).

One may ask: who cares? Aren't economic models abstractions and simplifications that can never fully reflect reality? The answer is the following: a key feature of heterodox economics and institutional economics in particular is that if a story has to be told and explanations provided, one should get the story right. Thus one needs to pay attention to the starting assumptions, which need to be descriptive and realistic. Otherwise one can make no sense of why increases in excess reserves do not necessarily lead to increases in the money supply, why they don't lead to faster inflation, or why positive interest rates on reserves do not lead to reduced bank credit, unless one relies on the mystical zero lower bound and liquidity trap that Paul Krugman is so fond of. Goodwin et al. (2014: xvii) claim that their book was written 'to encourage engaged and critical thinking' and that it provides an answer to textbooks that 'too often present material that not only abstracts from reality but sometimes directly contradicts it'. Then, on the question of monetary economics, they should go for the reality described by central bankers and post-Keynesian authors.

Another problem with the Goodwin et al. (2014) textbook, at least from my standpoint, is that in their chapter on fiscal policy they give quite a lot of attention to the mainstream crowding-out effects attributed to government deficits, which would raise interest rates. 
When they try to minimize the importance of these negative effects, they argue that the interest-elasticity of investment is small or they argue that during a recession there is excess saving, so that there are idle loanable funds out there that could provide finance for investment despite the government deficit. So they essentially concede the validity of the loanable funds theory and of the crowding-out argument, only trying to restrict the size of the effects of crowding-out (Goodwin et al. 2014: 244). To their merit, there is a brief discussion of a possible crowding-in effect, based on the fact that public infrastructures (good roads and so on) may help firms to become more profitable - certainly a valid and important line of reasoning. But the macroeconomic argument of Kalecki, that government deficits raise corporate profits through a flow-of-funds analysis, is nowhere to be found.

My purpose here is not to stymie the efforts of Goodwin, Harris and their colleagues to create an alternative and eclectic textbook, but simply to argue that they are not heterodox enough, or at the very least that they are less heterodox than a number of central bankers when it comes to monetary theory!

\section{CONCLUSION}

I conclude with another anecdote. With Mario Seccareccia, I wrote the Canadian version of the Baumol and Blinder introductory textbook (Baumol et al. 2010), one of the most Keynesian first-year US textbooks on the market. As David Colander has pointed out in his contribution to this issue (Colander 2015), each chapter in a textbook is reviewed by a large number of potential users, who often put pressure on the publisher and the authors not to move too far away from what they are used to work with. Reviewers were praising our two chapters on the banking system and the central bank, which were essentially all about post-Keynesian monetary theory, where we explained that the amount of loans that banks grant are not constrained by reserves and are more likely to be limited by their fear of losses, and that the central bank is pursuing defensive operations, trying to provide the amount of reserves being demanded by the banking system at the target rate set by the central bank. But some of the same reviewers were also imploring us to add a section describing the money multiplier process within a fractional-reserve banking system, apparently not realizing that such an addition would have been totally incoherent with the rest of the chapters. They begged us to have it in the main text, or at least in an appendix. While we agreed to make many of the suggested changes in other chapters, we held on and declined to do so in this case, arguing that the money multiplier story was false, on top of being a useless complication. This may explain (in part) the fact that the publisher has not (so far) asked us to do a second edition!

\section{REFERENCES}

Athreya, K. (2013): Big Ideas in Macroeconomics: A Nontechnical View, Cambridge, MA: MIT Press. Baumol, W.J., Blinder, A., Lavoie, M., Seccareccia, M. (2010): Macroeconomics: Principles and Policy, First Canadian Edition, Toronto: Nelson.

Bindseil, U., König, P.J. (2013): Basil J. Moore's Horizontalists and Verticalists: an appraisal 25 years later, in: Review of Keynesian Economics, 1(4), 383-390.

Blanchard, O. (2014) : Where dangers lurks, in: Finance and Development, September, 28-31.

Colander, D. (2010): The economics profession, the financial crisis, and method, in: Journal of Economic Methodology, 17, 419-427.

Colander, D. (2015): Why economics textbooks should, but don't, and won't, change, in: European Journal of Economics and Economic Policy: Intervention, 12(2), 229-235. 
Colander, D., Rothschild, C. (2009): Complexity and macro pedagogy: the complexity vision as a bridge between graduate and undergraduate macro, in: Fontana, G., Setterfield, M. (eds), Macroeconomic Theory and Macroeconomic Pedagogy, Basingstoke, UK: Palgrave Macmillan, 118-130. Cordonnier, L. (2014): La Liquidation, Paris: Les Liens qui Libèrent.

Garcia Duarte, P. (2012): Not going away? Microfoundations in the making of a new consensus in macroeconomics, in: Garcia Duarte, P., Tadeu Lima, G. (eds), Microfoundations Reconsidered: The Relationship of Micro and Macroeconomics in Historical Perspective, Cheltenham, UK and Northampton, MA: Edward Elgar, 190-237.

Goodhart, C.A.E. (2009): The continuing muddles of monetary theory: a steadfast refusal to face facts, in: Economica, 76, 821-830.

Goodwin, N., Harris, J., Nelson, J.E., Roach, B., Torras, M. (2014): Macroeconomics in Context, Second Edition, Armonk, NY: M.E. Sharpe.

International Student Initiative for Pluralism in Economics (2014): An international call for pluralism in economics, URL: http://www.isipe.net/open-letter/

Kaldor, N. (1972): The irrelevance of equilibrium economics, in: Economic Journal, 82, 1237-1252.

Keister, T., McAndrews, J. (2009): Why are banks holding so many excess reserves?, in: Federal Reserve Bank of New York Current Issues in Economics and Finance, 15(8), 1-10.

Keister, T., Martin, A., McAndrews, J. (2008): Divorcing money from monetary policy, in: Federal Reserve Bank of New York Economic Policy Review, September, 41-56.

Lavoie, M. (2009): Book review of Microeconomics in Context, second edition, and Macroeconomics in Context, in: Intervention: European Journal of Economics and Economic Policies, 6(2), 315-316.

Lavoie, M. (2012): Perspectives for post-Keynesian economics, in: Review of Political Economy, 24(2), $320-336$.

Lavoie, M. (2013): Teaching post-Keynesian economics in a mainstream department, in: Jespersen, J., Madsen, M.O. (eds), Teaching Post Keynesian Economics, Cheltenham, UK and Northampton, MA: Edward Elgar, 12-33.

Lavoie, M. (2014): Post-Keynesian Economics: New Foundations, Cheltenham, UK and Northampton, MA: Edward Elgar.

Lavoie, M., Niechoj, T. (2013): Interview with Fernando Cardim de Carvalho, in: European Journal of Economics and Economic Policies: Intervention, 10(3), 270-273.

Lee, F.S., Elsner, W. (eds) (2010): Evaluating Economic Research in a Contested Discipline: Rankings, Pluralism, and the Future of Heterodox Economics, Chichester, UK: John Wiley.

Lee, F.S., Harley, S. (1998): Peer review, the research assessment exercise and the demise of non-mainstream economics, in: Capital \& Class, 66, 23-51.

Lee, F.S., Lavoie, M. (eds) (2013): In Defense of Post-Keynesian and Heterodox Economics: Response to their Critics, London: Routledge.

Mankiw, G. (2015): Principles of Macroeconomics, Seventh Edition, Stamford, CT: Cengage.

McCombie, J. (2015): Book review of Marc Lavoie, Post-Keynesian Economics: New Foundations, in: European Journal of Economics and Economic Policy: Intervention, 12(2), 243-248.

McLeay, M., Radia, A., Thomas, R. (2014): Money creation in the modern economy, in: Bank of England Quarterly Bulletin, 1st Quarter, 14-27.

Moore, B.J. (1988): Horizontalists and Verticalists: The Macroeconomics of Credit Money, Cambridge, UK: Cambridge University Press.

Morgan, J. (2014): Pluralism, heterodoxy, and the prospects for a new Economics Curriculum: assessing the potential of INET, What's the Use of Economics and the CORE project, in: URL: http:// www.hetecon.net/documents/The_prospects_for_a_new_economic_curriculum.pdf.

Ragan, C. (2014): In defence of Economics 101, 21 October 2014, in: URL: https://secure.globeadvisor. com/servlet/ArticleNews/story/gam/20141021/RBELRAGAN.

Reissl, S. (2014): INET, 3 June 2014, in: URL: http://gurwes.wordpress.com/tag/inet/.

Rogers, C. (2014): Why 'state of the art' monetary theory was unable to anticipate the global financial crisis: a child's guide, in: European Journal of Economics and Economic Policy: Intervention, 11(3), 300-314. 